Article DOI: https://doi.org/10.35219/history.2017.05

\title{
Vitalie PONOMARIOV
}

\section{UNELE ASPECTE ALE ACTIVITĂŢII COMUNISTE DIN BASARABIA ÎN ANII 1922-1923}

Some Aspects Concerning Communist Activity in Bessarabia between 1922-1923

\begin{abstract}
This study covers important aspects and moments from the affiliation of the illegal Communist organisation in Bessarabia to the structures of the Communist Party from Romania in 1922-1923. The author used a vast material, including unpublished documents from the Archives of the Republic of Moldova, Romania and Ukraine.

Keywords: Romania, Bessarabia, Communist movement, Communist International, Balkan Communist Federation, Communist Party from Romania.

Trecerea organizaţiei regionale basarabene în subordinea $\mathrm{CC}$ al P.C. din România. Consideraţii istoriografice

La începutul anului 1922, Comitetul Executiv al Internaţionalei Comuniste a pus în discuţie problema trecerii organizaţiei comuniste basarabene în componenţa Partidului Comunist din România. În acest sens, la indicaţiile Cominternului a fost lichidat Biroul Partidului Comunist al Basarabiei şi Bucovinei, organizaţie în subordinea C.C. al P.C. (b) din Ucraina, care la 11 noiembrie 1921 substituise secţia din Odessa a Zakordotului. ${ }^{1}$ La 6 februarie 1922, în cadrul consfătuirii reprezentanţilor partidelor comuniste din cadrul Federaţiei Comuniste Balcanice ${ }^{2}$ la care a participat şi Vasil Kolarov, membru al C.E. al Internaţionalei Comuniste, a fost examinată problema lichidării Biroului basarabeano-bucovinean şi s-a decis
\end{abstract}

\footnotetext{
* Universitatea de Stat „B.P. Haşdeu” din Cahul, Universitatea „Dunărea de Jos” din Galaţi; vitalie.ponomariov@gmail.com.

1 Коммунистическое подполье Бессарабии (1918-1940). Т. 1. - Кишинев: Картя Молдовеняскэ, 1987, p. 324; Arhiva Organizaţiilor Politice din Republica Moldova (în continuare AOSPRM), F. 50, inv. 3, d. 433, f. 1, 13-14.

${ }^{2}$ Potrivit procesului verbal, la consfătuirea din 6 februarie 1922 au participat G. Safarov, V. Kolarov, D. Popov (reprezentantul partidului comunist din Bulgaria), S. Marcovich (din partea partidului comunist din Iugoslavia), P. Vompe şi Al. Grinştein (bolşevic basarabean, fost membru al secţiei din Odessa a Zakordotului). - AOSPRM, F. 50, inv. 4, d. 6, f. 1-2. De menţionat că la consfătuire nu au participat reprezentanţi ai Partidului Comunist din România.
} 
transmiterea „aparatului de legătură” a fostei structuri către Secţia de Relaţii Internaţionale (O.M.S. - Otdel Mezhdunarodnoy Svyazi $)^{3}$ a Cominternului. Aceasta din urmă trebuia „să cerceteze aparatul de legătură, să facă schimbările necesare şi reduceri în cadrul acestuia şi să conducă în continuare toate legăturile cu România (cu organizaţiile subversive comuniste din România - n.n.)". ${ }^{4}$ Drept urmare, C.C. al P.C. din România a primit directiva de a lua în subordinea sa şi integra în cadrul mişcării comuniste române organizaţiile comuniste din Basarabia şi Bucovina, sarcină pe care a început să o realizeze chiar în luna februarie 1922, profitând în acest sens de alegerile parlamentare. De menţionat că organizaţia comunistă din Basarabia va accepta formal decizia C.E. al Internaţionalei Comuniste privind intrarea sa în componenţa Partidului Comunist din România abia în august 1922, cu ocazia conferinţei regionale de partid. ${ }^{5}$

Problema trecerii în 1922 a organizaţiei regionale de partid din Basarabia în subordinea C.C. al Partidul Comunist din România a fost apreciată diferit în istoriografie.

Istoriografia sovietică a căutat să acrediteze ideea că decizia C.E. al Internaţionalei Comuniste şi apoi rezoluţia conferinţei organizaţiei de partid din Basarabia din august 1922 stabileau intrarea temporară a organizaţiei comuniste regionale în componenţa P.C. din România. Astfel, potrivit istoricilor sovietici, era vorba de adoptarea unei tactici de moment, care presupunea acţiuni conjugate ale comuniştilor basarabeni şi români în cadrul unui partid marxist unic, pentru „,ăsturnarea orânduirii burghezo-moşiereşti din România, reinstaurarea puterii Sovietelor în Basarabia şi reunirea acesteia cu Patria socialistă" ${ }^{6}$ În lucrarea Очерки истории Коммунистической Партии Молдавии (Schiţe de istorie a Partidului Comunist din Moldova) ${ }^{7}$, publicată la Chişinău în 1981, autorii susţin că situaţia internaţională, sarcinile de mobilizare a maselor la luptă împotriva „claselor exploatatoare” şi pentru ,realipirea la Patria Sovietică” au fost premisele care au dus la unificarea acţiunilor organizaţiei bolşevice din Basarabia cu cele ale comuniştilor

\footnotetext{
${ }^{3}$ Secţia respectivă coordona activităţile subversive şi conspirative ale agenţilor comunişti în străinătate.

${ }^{4}$ AOSPRM, F. 50, inv. 4, d. 6, f. 1.

${ }^{5}$ De menţionat că, până în momentul de faţă, atât rezoluţia C.E. al Internaţionalei Comuniste privind trecerea organizaţiei comuniste din Basarabia în subordinea C.C. al P.C.R., cât şi rezoluţia conferinţei regionale de partid din Basarabia din august 1922 încă nu au fost găsite. Mai multe documente provenind din cadrul mişcării comuniste din Basarabia fac referinţă însă la aceste rezoluții.

6 Коммунистическое подполье Бессарабии (1918-1940). Т. ІІ, Кишинев: Картя Молдовеняскэ, 1988, p. 6.

7 Очерки истории Коммунистической Партии Молдавии, Кишинев: Картя Молдовеняскэ, 1981.
} 
români. „În aceste condiţii complicate, în august 1922, comuniştii din Basarabia au intrat temporar în componenţa P.C.R., menţinând însă în continuare legături cu partidul lor leninist - P.C.(b) din Rusia, cu P.C.(b) din Ucraina, care acordau forţelor revoluţionare un ajutor politico-organizatoric inestimabil, în lupta lor de eliberare socială şi naţională". ${ }^{8}$

De alte păreri sunt istoricii care au cercetat problematica mişcării subversive comuniste din Basarabia în perioada de după căderea comunismului. De exemplu, istoricul Ludmila Rotari susţine că decizia C.E. al Internaţionalei Comuniste poate fi considerată drept prima acceptare indirectă a faptului că Basarabia aparţinea României. De această schimbare nu au ştiut însă să profite comuniştii români (în fapt străini), funcţionari ai Cominternului. În legătură cu aceasta, Ludmila Rotari încearcă să explice motivul care i-a făcut pe istoricii sovietici să vorbească despre decizia amintită folosind menţiunea temporar, considerând că ei au căutat să justifice prin această interpretare acţiunile guvernului sovietic din anul 1940. ${ }^{9}$ Istoricul Gheorghe E. Cojocaru consideră că încadrarea din august 1922 a organizaţiei comuniste din Basarabia, nesemnificativă numeric, în structurile Partidului Comunist Român, s-a făcut la comanda Moscovei şi în scopul sporirii potenţialului forţelor antiromâneşti. ${ }^{10}$

$\mathrm{Nu}$ ştim sigur care a fost intenţia adevărată care a stat la baza deciziei C.E. al Internaţionalei Comuniste, dat fiind faptul că nu a fost găsit încă acest document care, cu siguranţă, ar pune punctul pe $i$ în această întrebare. E vorba despre prima recunoaştere indirectă a Unirii Basarabiei cu România de către Comintern sau a fost o acţiune tactică a P.C. (b) din Rusia dictată de noile realităţi intervenite în relaţiile sovieto-române la răscrucea anilor 1920-1921, ajustată la strategia cominternistă de realizare a revoluţiei proletariatului la nivel mondial? Suntem înclinaţi să susţinem mai curând cea de-a doua ipoteză, având în vedere faptul că aceasta este confirmată de mai multe documente ce provin din cadrul mişcării comuniste internaţionale, dar şi a celei din Basarabia. În acest sens este relevant textul unei adresări făcute de un grup de comunişti basarabeni celui de-al V-lea Congres al Internaţionalei Comuniste (17 iunie-8 iulie 1924) cu privire la problema Basarabiei şi a mişcării comuniste din provincie, precum şi privind divergenţele legate de această problemă, prezente în cadrul P.C. din România. ${ }^{11}$ Potrivit documentului respectiv, trecerea organizaţiei comuniste din Basarabia în componenţa P.C.R. a fost decisă din consideraţii

\footnotetext{
${ }^{8}$ Ibidem, p. 203.

${ }^{9}$ Ludmila Rotari. Mişcarea subversivă în Basarabia în anii 1918-1924, Bucureşti: Editura Enciclopedică, 2004, p. 196.

${ }^{10}$ Gheorghe E Cojocaru. Integrarea Basarabiei în cadrul României (1918-1923), Bucureşti: Editura SEMNE, 1997, p. 129.

${ }^{11}$ AOSPRM, F. 50, inv. 2, d. 149, f. 13-15.
} 
diplomatice, în condiţiile noilor realităţi intervenite în relaţiile Rusiei Sovietice cu România la răscrucea anilor 1920 şi 1921, care cereau coexistenţa paşnică a celor două state. „Deşi Rusia Sovietică nu recunoştea Basarabia a României, interesele de convieţuire paşnică ale ambelor state cereau să fie întrerupte relaţiile organizaţiilor basarabene cu structurile P.C. (b) R., care se aflau pe malul stâng al Nistrului, iar pentru legătura cu Cominternul acestea urmau să facă parte din P.C. Român"12.

Primii paşi de încadrare a organizaţiei comuniste basarabene în P.C. din România. Alegerile parlamentare din martie 1922

La 17 ianuarie 1922, sesiunea C.E. al Federaţiei Comuniste Balcanice, abordând printre alte probleme şi „,chestiunea română”, a stabilit ca partidul comunist român să activeze în condiţii de legalitate şi să se declare categoric ,,̂mpotriva acţiunilor teroriste, ca şi împotriva formării de grupări şi organizaţii teroriste şi militarea de orice fel." "' I3 In aceste condiţii, P.C. din România a demarat în februarie 1922 acţiunile de integrare a organizaţiei bolşevice din Basarabia, moment facilitat de alegerile parlamentare stabilite pentru luna martie a aceluiaşi an.

Se ştie că alegerile parlamentare din martie 1922 au constituit momentul în care, pentru prima dată, P.C. din România a luat parte la o acţiune politică la nivel naţional, angajându-se în campania electorală cu un ,program şi lozinci revoluţionare". ${ }^{14}$ Campania electorală din 1922 a fost favorabilă pentru dezvoltarea P.C. din România, inclusiv în sensul iniţierii unei conlucrări cu bolşevicii din Basarabia în cadrul aceluiaşi partid. În timpul alegerilor, se relevă într-un raport a lui M. Pauker prezentat C.E. al Internaţionalei Comuniste în august 1922: ,am reuşit (...) să pătrundem pentru prima oară în Basarabia, să edităm acolo un ziar şi să prezentăm o listă". ${ }^{15}$ De menţionat că pentru organizaţia comunistă din Basarabia participarea în alegerile parlamentare din martie 1922 a însemnat, în acelaşi timp, începutul trecerii la activitatea legală de partid.

\footnotetext{
${ }^{12}$ Ibidem, f. 13.

${ }^{13}$ Copilăria comunismului românesc în arhiva Cominternului, Bucureşti, 2001, p. 68-71 (Raportul lui Gheorghe Dimitrov «Dietrich» din 21 ianuarie 1922 adresat Prezidiumului CE al Internaţionalei Comuniste).

${ }^{14}$ Mihail Rusenescu, Ioan Saizu. Viaţa politică în România 1922-1928, Bucureşti: Editura politică, 1979, p. 144. În unele documente provenind din cadrul mişcării comuniste din România se remarcă importanța participării P.C.R. în alegerile parlamentare din martie 1922. De exemplu, în raportul întocmit de căre M. Pauker şi prezentat CE al Internaţionalei Comuniste în august 1922 se arată: „Pentru prima oară în România, un partid cu teze revoluţionare s-a angajat în alegeri. Pentru prima oară, deviza dictaturii poporului a fost opusă deschis Constituantei”. A se vedea în acest sens: Copilăria comunismului românesc în arhiva Cominternului, p. 88.

${ }^{15}$ Ibidem, p. 87.
} 
La 15 februarie 1922 comuniştii basarabeni au acceptat propunerea C.C. al P.C. din România de a participa în alegerile parlamentare cu o listă comună de candidaţi. În acelaşi timp, un grup de bolşevici basarabeni ce se aflau la acel moment în închisoarea de la Văcăreşti ${ }^{16}$ a făcut o adresare către tovarăşii lor din Basarabia, chemându-i să se implice în campania electorală şi să susţină lista candidaţilor comunişti. ${ }^{17}$ După o scurtă trecere în revistă a problemelor mişcării comuniste din provincie, autorii scrisorii menţionau că „tânărul partid comunist din România, după ce a izgonit centriştii din rândurile sale (...) şi-a trimis îndată reprezentanţii săi în Basarabia, pentru a vă ajuta să vă încadraţi în viaţa politică”. Ei chemau: „Tovarăşi! Noi ştim că priviţi cu antipatie viaţa politică din România. Noi înşine v-am chemat, în noiembrie 1919, să boicotaţi alegerile (...) La moment, participarea este datoria fiecărui muncitor, care nu vrea să trădeze interesele sale de clasă (...) Pentru victoria listei comuniştilor!"18. La 3 martie 1922 pe paginile ziarului Innainte a fost publicat un apel asemănător, adresat muncitorilor din oraşul Chişinău. Deşi erau conştienţi de scorul electoral nesemnificativ pe care urmau să-1 obţină, comuniştii priveau alegerile parlamentare ca pe o oportunitate de a recruta noi activişti de partid şi de a mobiliza muncitorii la lupta de clasă. În cadrul apelului a fost inserată lista comună de candidaţi comunişti: 1) Al. Rubinştein, 2) Gh. Tănase, 3) T. Marin, 4) Gh. Cristescu, 5) B. Stefanov, 6) P. Constantinescu-Iaşi, 7) D. Fabian-Finkelştein şi 8) Al. Dobrogeanu-Gherea. De menţionat că ultimii şase din cei opt candidaţi de pe lista comună se aflau la momentul alegerilor în închisoare. ${ }^{19}$

În timpul campaniei electorale, la Chişinău a fost editat ziarul Inainte („Вперед”) - primul ziar legal al comuniştilor din Basarabia. Acesta a fost tipărit cu susţinerea financiară a P.C. din România şi cu ajutorul nemijlocit al comunistului ieşean Gh. Tănase, desemnat responsabil de editare de către C.C. de la Bucureşti, ne arată raportul lui M. Pauker. ${ }^{20}$ In redacţia publicaţiei au fost încadraţi bolşevicii basarabeni Al. Rubinştein şi S. Timov (Tinkelman), secretarul comitetului regional al Comsomol-ului ${ }^{21}$. Ziarul era editat de trei ori pe săptămână, cu patru pagini, din care trei erau redactate în limba rusă şi una în limba română. De menţionat că ziarul

\footnotetext{
${ }^{16}$ Este vorba despre bolşevicii basarabeni P. Tkacenko, S. Bubnovskii, Iu. Peceniuk, M. Serebrier, M. Blank, M. Boceacer, M. Broitman, care au fost arestaţi pe parcursul anului 1921 şi erau judecaţi în cadrul ,,procesului celor 270”. - A se vedea: Коммунистическое подполье Бессарабии (1918-1940). Т. 1, р. 336.

17 Ibidem, p. 332-336. De notat că adresarea în cauză a fost publicată în ziarul comunist Socialismul din 4 martie 1922.

${ }^{18}$ Ibidem, p. 333-334.

${ }^{19}$ Ibidem, p. 336-338.

${ }^{20}$ Copilăria comunismului românesc în arhiva Cominternului, p. 88.

${ }^{21}$ Коммунистическое подполье Бессарабии (1918-1940). Т. 1, p. 336.
} 
Inainte a fost tipărit numai în perioada campaniei electorale, după alegeri fiind sistată editarea acestuia „din lipsă de bani”. ${ }^{22}$ În legătură cu sistarea publicării ziarului, în raportul amintit se arată insatisfacţiile C.C. al P.C. din România privitor la rezultatele obţinute în Basarabia în urma participări în campania electorală. În acest sens, M. Pauker susţinea: „Campania electorală din Basarabia putea avea valoare numai în cazul în care noi am fi fost în stare să continuăm publicarea ziarului şi să organizăm masele muncitoreşti, cel puţin din punct de vedere sindical. $\mathrm{N}$-am putut realiza aceasta. Situaţia generală, teroarea, dezorganizarea (...) în două părţi explică folosirea incompletă a campaniei electorale". ${ }^{23}$

Problemele integrării organizaţiei comuniste din Basarabia în P.C. din România: separatismul pro-sovietic, tendinţele teroriste şi spionajul

Deşi, în contextul campaniei electorale din 1922, a reuşit să pătrundă în Basarabia şi a obţinut anumite rezultate în sensul conlucrării cu organizaţia comunistă de aici, C.C. al P.C.R. a întâlnit în acelaşi timp o rezistenţă serioasă, tendinţe separatiste precum şi alte piedici din partea majorităţii covârşitoare a bolşevicilor din Basarabia. Aceasta se explica prin faptul că ei se orientau spre Rusia Sovietică şi erau eficienţi doar în condiţiile de activitate ilegală subversivă, mizând pe situaţia revoluţionară. ${ }^{24}$ În acest sens sunt relevante relatările lui M. Pauker din raportul din august $1922^{25}$, pe care l-am menţionat mai sus. Referindu-se la organizarea şi activitatea în ilegalitate, comunistul român relatează: „Un pericol continuu pentru partid venea de la tovarăşii rămaşi de la fostele organizaţii ilegale din Basarabia, care aveau ei înşişi o existenţă ilegală. A trebuit să-i dezinteresăm şi pentru aceasta a fost nevoie de mulţi bani". ${ }^{26}$ M. Pauker relevă informaţii despre conflictele interne din partid, subliniind îndeosebi problemele C.C. al P.C.R. în relaţiile cu organizaţia basarabeană. El arată că aceasta se afla sub ,larga protecţie a Zakordot-ului de la Odessa” care trimitea „numai bani şi provocatori”, ceea ce a avut drept rezultat arestarea a numeroşi bolşevici şi descoperirea a diferitor

\footnotetext{
${ }^{22}$ Copilăria comunismului românesc în arhiva Cominternului, p. 88-89.

${ }^{23}$ Ibidem, p.88.

${ }^{24}$ AOSPRM, F. 50, inv. 2, d. 149, f. 13-15 (Scrisoarea unui grup de comunişti basarabeni, adresată Congresului al V-lea al Internaţionalei Comuniste, referitoare la problema basarabeană şi a mişcării comuniste din Basarabia şi la divergenţele în acest sens din cadrul P.C. din România); Ibidem, inv. 3, d. 105, f. 1 (Raportul informativ privind mişcarea comunistă din Basarabia, din 28 decembrie 1925, semnat de către E. Sovetova «Nora», secretarul comitetului regional din Basarabia al Comsomol-ului).

${ }^{25}$ Copilăria comunismului românesc în arhiva Cominternului, p. 71-98.

${ }^{26}$ Ibidem, p. 91.
} 
comitete $^{27}$ şi, în ultimă instanţă, a facilitat instaurarea hegemoniei unui oarecare Sania ${ }^{28}$, alias Bonaparte, asupra mişcării comuniste din Basarabia. Acesta din urmă a rupt legăturile cu C.C. de la Bucureşti şi, dispunând de resurse băneşti considerabile $^{29}$, a atras sub controlul său mişcarea comunistă din Bucovina şi Iaşi, atrăgându-1 de partea sa şi pe Gh. Tănase ${ }^{30}$ şi astfel determinând scindarea partidului în două. Abia după arestarea lui Sania şi a întreruperii legăturilor cu Odessa, P.C. din România a adus, „puţin câte puţin, fie şi formal, Basarabia şi Iaşiul” sub conducerea sa. M. Pauker relevă faptul că în urma conflictului nu a mai rămas nici o organizaţie de partid şi de tineret în Basarabia, ceea ce, considera el, era bilanţul activităţii Zakordot-ului. ${ }^{31}$

În raport se vorbeşte şi despre practica Razvedot-ului ${ }^{32}$ de a folosi organizaţiile comuniste din România ca mijloc de informare, ceea ce, menţiona M. Pauker, punea în mare primejdie partidul. Îndeosebi colaborau cu structurile sovietice de spionaj bolşevicii din Basarabia care „sunt gata mereu să aplece urechea de partea cealaltă a Nistrului şi sunt înclinaţi să stabilească relaţii ilegale, adică fără ştiinţa Comitetului Executiv (C.C. al P.C.R. - n.n.)". Sumele extraordinare de bani achitate de Razvedot îi atrăgea nu doar pe tovarăşi să devină funcţionari ai acestei structuri de spionaj, ci şi pe detectivii români. ${ }^{33}$ De asemenea, raportul relatează şi despre tendinţele teroriste radicale ale bolşevicilor basarabeni, care sunt cauzate de teroarea autorităţilor române şi ,primesc mereu asistenţă morală şi materială din partea cealaltă a Nistrului” ${ }^{34}$.

Bolşevicii basarabeni menţineau legături cu structurile sovietice din stânga Nistrului nu doar din considerente financiare, ci, în primul rând, din cauza tendinţelor lor separatiste în raport cu România şi implicit faţă de C.C. al P.C.R. Ei au interpretat decizia C.E. al Internaţionalei Comuniste privind trecerea lor în subordinea Comitetului Central de la Bucureşti drept un act prin care ar fi fost recunoscută indirect Unirea Basarabiei cu România. De menţionat că în aceiaşi

\footnotetext{
${ }^{27}$ Ibidem, p. 88.

${ }^{28}$ Este vorba despre bolşevicul basarabean Alexandr Dobroceaev (Wolf Beer).

29 În acelaşi raport, M. Pauker relatează despre cheltuielile considerabile pe care le-a făcut comitetul basarabean sub conducerea lui Sania în perioada campaniei electorale: „Este de remarcat faptul că în timpul campaniei electorale şi în toată luna următoare, cu editarea zilnică a ziarului nostru şi cu editarea săptămânală a ziarului tineretului, susținut de noi, $n$ am cheltuit decât 100.000 lei, pe când Comitetul Central din Basarabia (Sania) a cheltuit doar în timpul campaniei electorale 100.000 de mărci de la Sofia şi 600.000 de lei de la Odessa". A se vedea Copilăria comunismului românesc în arhiva Cominternului, p. 89.

${ }^{30} \mathrm{Gh}$. Tănase a fost un lider important al socialiştilor din Iaşi.

${ }^{31}$ Copilăria comunismului românesc în arhiva Cominternului, p. 88-89.

${ }^{32}$ Este vorba despre Serviciul de spionaj sovietic.

${ }^{33}$ Copilăria comunismului românesc în arhiva Cominternului, p. 95.

${ }^{34}$ Ibidem, p. 93-94.
} 
termeni a înţeles decizia Internaţionalei Comuniste şi conducerea P.C. din România, precum şi unii comunişti din Basarabia. Cei din urmă s-au conformat deciziei şi au considerat că este necesar să schimbe orientarea politică a mişcării comuniste din Basarabia: ,adică să lupte cu atracţia spre Rusia a ţărănimii basarabene, să includă muncitorul orăşean şi ţăranul în cursul vieţii politice româneşti”. Ei au pus la baza tacticii lor „unirea definitivă şi ireversibilă a Basarabiei cu România”. ${ }^{35}$

Cea mai mare parte a agenţilor comunişti din Basarabia au condamnat însă decizia Internaţionalei Comuniste. Ei erau nemulţumiţi că n-au primit nici un ordin din partea P.C. (b) din Rusia de a întrerupe relaţiile cu structurile sovietice din stânga Nistrului şi de a lucra în subordinea C.C. al P.C. din România. ${ }^{36}$ Drept consecinţă, în rândurile mişcării comuniste basarabene se instaurase o stare de inactivitate, însoţită de plecări a numeroşi bolşevici din Basarabia în Rusia Sovietică. Starea de asediu şi, în acest context, măsurile prompte şi dure luate de Siguranţă şi Poliţie împotriva tuturor celor implicaţi sau cel puţin suspectaţi de activitate subversivă, pe de o parte, şi directivele de a trece la activitatea legală de partid, pe de altă parte, au accentuat nemulţumirile şi au sporit numărul celor care alegeau să se refugieze în stânga Nistrului. În acest sens, în raportul lui M. Pauker din august 1922 se arată: „Din cauza terorii care domnea aici (în Basarabia - n.n.), tovarăşii erau stăpâniţi de panică. Pe circa zece amnistiaţi a trebuit să-i trecem frontiera. Alţii au fugit de la noi, peste Nistru, pe ascuns. Aproape 40 de amnistiaţi au fost menţinuţi în stare de arest de către autorităţile militare, în scop de şantaj la sânge. Câţiva tovarăşi (printre cei mai buni) au fost pur şi simplu împuşcaţi, iar execuţia constatată oficial. $\mathrm{Cu}$ preţul celor mai mari dificultăţi, am ajuns să menţinem la Chişinău un tovarăş din Basarabia şi să formăm o secţie ilegală şi un comitet regional". Peste puţin timp, comitetul regional s-a ridicat contra partidului şi a trimis un ultimatum, conform căruia ,secţia nu va continua să aparţină partidului decât în schimbul unui vărsământ imediat de aproape 250.000 de lei şi a trimiterii în străinătate a 68 de tovarăşi”. ${ }^{37}$ Pentru a aplana conflictul, M. Pauker a mers la Chişinău unde a convins agenţii comunişti de acolo să renunţe la ultimatum şi să revină în partid. El constata că starea de spirit a tovarăşilor din Basarabia era de o nervozitate extremă, iar cauza adevărată a dificultăţilor apărute între organizaţia

${ }^{35}$ AOSPRM, F. 50, inv. 2, d. 149, f. 13-15 (Scrisoarea unui grup de comunişti basarabeni, adresată Congresului al V-lea al Internaţionalei Comuniste, referitoare la problema basarabeană şi a mişcării comuniste din Basarabia şi la divergenţele în acest sens din cadrul P.C. din România).

${ }^{36}$ Copilăria comunismului românesc în arhiva Cominternului, p. 93; A se vedea pentru aceasta şi declaraţia unui grup de bolşevici basarabeni, adresată Comisiei pentru problema română pe lângă CE al Internaţionalei Comuniste, în noiembrie 1923. - AOSPRM, F. 50, inv. 3, d. 87, f. 25-26.

${ }^{37}$ Ibidem. 
regională şi C.C. al P.C.R. pornea de la tendinţele separatiste ale bolşevicilor basarabeni. ${ }^{38}$

Amplificarea conflictului între organizaţia comunistă din Basarabia şi C.C. al P.C. din România. Autodizolvarea comitetului regional de partid

Organizaţia comunistă din Basarabia a acceptat formal decizia C.E. al Internaţionalei Comuniste privind trecerea în subordinea C.C. al P.C. din România abia în august 1922, cu ocazia conferinţei regionale de partid. Rezoluţia adoptată de conferinţă în acest sens stabilea ,intrarea determinantă" a mişcării comuniste basarabene în componenţa partidului comunist român. ${ }^{39}$ De menţionat că textul rezoluţiei nu a fost găsit deocamdată. Informaţii despre acest act sunt însă relevate de unele documente mai târzii ale mişcării comuniste din Basarabia, cum ar fi de exemplu raportul din 28 decembrie 1925 semnat de către E. Sovetova (conspirativ Nora), secretarul comitetului regional al Comsomol-ului. ${ }^{40}$

Îndată după conferinţa regională de partid s-a desfăşurat o campanie de informare a membrilor mişcării comuniste basarabene cu privire la schimbările de ordin organizatoric şi tactic, relatează raportul menţionat. ${ }^{41}$ Agenţii comunişti responsabili de campanie explicau că momentul revoluţionar a trecut, iar activitatea de partid necesită o abordare nouă, fiind indicate în noile condiţii ,propaganda îndelungată, instruirea şi organizarea elementelor muncitoresc şi ţărănesc". În pofida acestui fapt, peste puţin timp, toţi bolşevicii cu stagiu care şi-au luat angajamentul să implementeze hotărârile conferinţei din august 1922 au abandonat activitatea de partid şi au plecat din Basarabia, invocând diferite motive. În opinia comunistei E. Sovetova, ei nu aveau de fapt experienţa necesară pentru ,activitatea îndelungată şi intensă de organizare şi de conducere a partidului comunist", fiind deprinşi cu activitatea ilegală şi lupta nemijlocită şi mizând, în trecut, pe situaţia revoluţionară. ${ }^{42}$ Astfel, deşi la conferinţa din august 1922 bolşevicii din Basarabia au acceptat formal trecerea în subordinea P.C. din România, ei vor continua să conteste decizia C.E. al Internaţionalei Comuniste, pe care o considerau inoportună din punct de vedere politic, tactic şi organizatoric în situaţia de atunci din Basarabia. Forma principală de contestare manifestată de către agenţii comunişti era abandonarea activităţii de partid din Basarabia şi plecarea lor în Rusia Sovietică.

\footnotetext{
${ }^{38}$ Ibidem.

${ }^{39}$ AOSPRM, F. 50, inv. 3, d. 105, f. 1-14.

${ }^{40}$ Ibidem.

${ }^{41}$ Ibidem, f. 1.

42 Ibidem.
} 
Divergenţele de poziţii privind încadrarea organizaţiei comuniste din Basarabia în P.C. din România, tendinţele teroriste şi separatismul bolşevicilor basarabeni, precum şi menţinerea legăturilor cu structurile sovietice din stânga Nistrului, inclusiv cu cele de spionaj, au dus la aprofundarea conflictului între C.C. de la Bucureşti, pe de o parte, şi organizaţia de partid basarabeană, pe de altă parte. În timpul lucrărilor Congresului al II-lea al P.C. din România (Ploieşti, 3-4 octombrie 1922), Haim Bogopolskii, reprezentantul comitetului regional de partid ${ }^{43}$, a încercat să prezinte păsul comuniştilor din Basarabia faţă de trecerea lor în subordinea C.C. al P.C.R. Însă din cauza ,intrigilor de culise şi a fraudelor” nu a fost posibilă expunerea poziţiei proprii pentru a ,duce lupta cu C.C. (al P.C. din România - n.n.)", se arată într-o declaraţie a unui grup de bolşevici basarabeni din toamna lui $1923 .^{44}$

De notat că la Congresul al II-lea al P.C.R. a fost pusă în discuţie problema naţională din România. ${ }^{45}$ Rezoluţia, adoptată în concordanţă cu hotărârile Conferinţei a V-a a Federaţiei Comuniste Balcanice (14-17 iunie 1922), stabilea că ,problema naţionalităţilor din România face parte integrantă din problema naţionalităţilor din Peninsula Balcanică, care e locuită de un conglomerat de numeroase naţionalităţi ce-şi vor cuceri deplina libertate naţională numai în cazul Republicii Socialiste Federative a Sfaturilor din Balcani". ${ }^{46}$ Astfel, P.C. din România a adoptat la congres o poziţie opusă viziunilor bolşevicilor din Basarabia în problema naţională, care se orientau spre Rusia Sovietică. Potrivit lor, mişcarea basarabeană putea fi ,puternică şi revoluţionară” doar în cazul în care „se orientează spre Patria Sovietică şi manifestă tendinţe centrifuge, clătinând stabilitatea politică a României Mari şi stimulând celelalte minorităţi naţionale la mişcare pentru autonomie şi independenţă", ${ }^{47}$

Nereuşind să-şi expună propria poziţie la congres şi nefiind de acord cu linia politică generală a P.C. din România privind problema naţională, precum şi confruntându-se cu starea de inactivitate generală şi părăsirea Basarabiei de către numeroşi activişti, comitetul comunist basarabean a refuzat să-şi ia în continuare responsabilitatea activităţii de partid şi, peste puţin timp după Congresul al II-lea al P.C.R., s-a autodizolvat. Despre aceasta a fost informat C.C. al P.C. din România,

\footnotetext{
${ }^{43}$ Коммунистическое подполье Бессарабии (1918-1940). Т. II, p. 16.

${ }^{44}$ AOSPRM, F. 50, inv. 3, d. 87, f. 25-28 (Declaraţia unui grup de bolşevici basarabeni adresată Comisiei pentru problema română pe lângă $\mathrm{CE}$ al Internaţionalei Comuniste în noiembrie 1923).

${ }^{45}$ Raportul cu privire la problema naţională din România a fost prezentat congresului de către comunistul Eugen Rosvan.

${ }^{46}$ Socialismul, Anul al XII-lea, nr. 192, 8 octombrie 1922; AOSPRM, F. 50, inv. 3, d. 80, f. 2.

${ }^{47}$ AOSPRM, F. 50, inv. 2, d. 149, f. 14.
} 
care nu a reacţionat însă în niciun fel la ştire. ${ }^{48}$ Drept urmare a luat amploare valul de plecări din Basarabia a activiştilor de partid: „Au început să plece în masă membrii organizaţiilor locale şi a celulelor, precum şi cei rămaşi singuri care au pierdut legăturile cu întreaga mişcare şi erau nemulţumiţi de situaţia de inactivitate dictată de condiţiile teroarei poliţieneşti de coşmar, îndreptate în primul rând împotriva lor. Plecările au continuat până în prezent (noiembrie 1923 - n.n.), ducând la concentrarea în Rusia a celor mai bune forţe ale mişcării comuniste basarabene, a nucleului conducător călit în activitatea revoluţionară". ${ }^{49}$ În aşa mod, în ultimele luni din 1922 mişcarea comunistă din Basarabia a fost paralizată totalmente. Mai multe documente de arhivă, unele din ele inedite ${ }^{50}$, relevă inexistenţa unei organizaţii comuniste regionale în Basarabia în perioada noiembrie 1922- 1925.

Conflictul între organizaţia regională din Basarabia şi C.C. al P.C. din România, abordat în cadrul Comisiei pentru problema română pe lângă C.E. al Cominternului

În septembrie 1923, în cadrul Comisiei secrete a C.E. al Internaţionalei Comuniste au fost puse în discuţie problemele mişcării comuniste din Basarabia, în baza raportului prezentat de către V. Miţkevici. Raportorul a informat pe cei prezenţi despre inexistenţa unei organizaţii de partid în această regiune, deşi existau condiţii prielnice de activitate. El a criticat P.C. din România ce se dovedise a fi slab, ineficient şi nu manifesta nici un interes faţă de organizarea activităţii în Basarabia unde ar fi existat câteva mici grupulețe, ce se orientau însă spre organizaţiile din Rusia şi Ucraina şi nu spre cea de la Bucureşti. Comisia a stabilit că problema privind activitatea în Basarabia urma să fie discutată la viitoarea sesiune a Federaţiei Comuniste Balcanice. ${ }^{51}$

Drept urmare, în scopul examinării conflictelor existente în cadrul P.C. din România, inclusiv a disensiunilor dintre agenţii comunişti din Basarabia şi C.C. de la Bucureşti, C.E. al Internaţionalei Comuniste a constituit Comisia pentru problema română şi a invitat la lucrările acesteia o delegaţie a P.C. din România. În acest sens, C.C. al P.C. din România a delegat la Moscova pe Al. Korosi-Crişan şi H. Sternberg. Într-o scrisoare adresată Prezidiumului C.E. al Internaţionalei Comuniste, la 17 octombrie 1923, cei doi comunişti români semnalau: „În ultimul timp, mai

\footnotetext{
${ }^{48}$ AOSPRM, F. 50, inv. 3, d. 87, f. 27.

${ }^{49}$ Ibidem.

${ }^{50}$ Ibidem, d. 105, f. 1-14 (Raportul informativ privind mişcarea comunistă din Basarabia, din 28 decembrie 1925, semnat de către E. Sovetova «Nora», secretarul comitetului regional din Basarabia al Comsomol-ului).

${ }^{51}$ Ludmila Rotari. Mişcarea subversivă în Basarabia în anii 1918-1924, p. 199.
} 
mulţi tovarăşi români, îndeosebi basarabeni, au părăsit ţara şi au emigrat în Rusia sovietică, neavând nici un motiv plauzibil pentru aceasta" ${ }^{, 52}$. Potrivit scrisorii, în Rusia se afla un grup semnificativ de tovarăşi (vreo 40 de persoane) care nu şi-au pierdut legalitatea şederii în România, printre ei fiind menţionaţi H. Bogopolskii, M. Serebrier, M. Boceacer, Niunea şi Lia Roitman, A. Toporovskaia, Tuba Mirskaia etc. Delegaţii C.C. al P.C. din România solicitau: „să fie luate măsuri severe pentru ca (...) prin intermediul P.C. din Rusia, ai cărui membri sunt, toţi tovarăşii să fie trimişi fără întârziere înapoi şi să fie transferaţi în subordinea P.C. din România". ${ }^{53}$

La începutul lunii noiembrie 1923 un grup de activişti de partid din Basarabia aflaţi în Rusia Sovietică au adresat o declaraţie Comisiei pentru problema română, în care se releva existența unui conflict între organizaţia regională din Basarabia şi C.C. al P.C. din România ${ }^{54}$. Semnatarii declaraţiei menţionau că ,acest conflict are, fără îndoială, rădăcini adânci, în primul rând din cauza divergenţelor tactice şi organizatorice dintre cele două organizaţii şi, în nici un caz, el nu poate fi privit ca o simplă ceartă". ${ }^{55}$ În acest document se mai arată că agenţii din Basarabia nu întreprinseseră nimic pentru a clarifica situaţia. Fiind faptul că C.C. al P.C. din România a privat-o de legăturile directe cu Internaţionala Comunistă, organizaţia de partid din Basarabia nu a avut posibilitatea să-şi facă cunoscut punctul de vedere inclusiv în ceea ce priveşte hotărârea ei de autodizolvare. $\mathrm{Cu}$ toate acestea, unii comunişti basarabeni au prezentat rapoarte în care vorbeau despre situaţia activităţii comuniste din Basarabia, dar care, din cauza caracterului individual şi neoficial, nau ajuns la Secretariatul Cominternului. Printre acestea se numără: raportul lui M. Zalkind, fost secretar al comitetului regional din Basarabia, înmânat reprezentantului Secţiei de Relaţii Internaţionale şi lui P. Vompe la cel de-al IV-lea Congres al Internaţionalei Comuniste şi raportul informativ semnat de comuniştii $\mathrm{H}$. Bogopolski, M. Zalkind şi Gh. Starâi care a fost prezentat lui V. Miţkevici, reprezentantul Secţiei de Relaţii Internaţionale.

Comuniştii basarabeni îşi fac cunoscută poziţia faţă de problemele existente în relaţiile lor cu C.C. al P.C. din România şi înaintează propuneri concrete privind soluţionarea acestora. Declaraţia punctează în acest sens următoarele:

1) Deşi aveau viziuni diferite referitor la includerea organizaţiei basarabene în rândurile P.C. din România, ei considerau decizia C.E. al Internaţionalei Comuniste obligatorie. În acelaşi timp, semnatarii declaraţiei consideră că „trecerea unei organizaţii regionale întregi dintr-o secţie în alta a Cominternului trebuia să fie pregătită în mod corespunzător de o conferinţă specială, iar decizia trebuia adoptată

\footnotetext{
${ }^{52}$ AOSPRM, F. 50, inv. 4, d. 87, f. 71, (fotocopie după originalul în limba germană).

${ }^{53}$ Ibidem.

${ }^{54}$ AOSPRM, F. 50, inv. 3, d. 87, f. 25-28.

${ }^{55}$ Ibidem, f. 25.
} 
de către delegaţi cu drepturi depline ai organizaţiei, ceea ce nu a avut loc, potrivit datelor absolut precise de care dispunem" ${ }^{\text {. }}$. Conform lor, decizia C.E. al Internaţionalei Comuniste a fost adusă la cunoştinţa activiştilor de partid din Basarabia de către C.C. al P.C. din România, care nu se bucura de încrederea celor din Basarabia.

2) Problema nu ţinea de lipsa de dorinţă a comuniştilor din Basarabia de a activa, ci de linia greşită a activităţii de partid adoptată de către C.C. al P.C. din România. Ei criticau C.C. al P.C. din România pentru că era alcătuit din ,intelectuali burghezi, proveniţi ieri din partidele burgheze din România (Pauker, Cruceanu, Macovei), ce au adus în rândurile mişcării comuniste spiritul de politicianism şi carierism politic, de intrigi de culise şi diplomaţie balcanică" ${ }^{57}$. În viziunea lor, P.C. din România „neavând tradiţii revoluţionare temeinice, fiind educat sub influenţa parlamentarismului oportunist în descompunere" era incapabil să activeze în condiţiile de teroare poliţienească. De asemenea, ei criticau C.C. al P.C.R. care a refuzat într-o formă evazivă să acorde ajutor organizaţiei din Basarabia, invocând lipsa de mijloace financiare şi de activiş̧i. Acest motiv nu era plauzibil, deoarece ei erau informaţi că C.C. al P.C.R. a primit de la Zakordot sume importante de bani destinate activităţii în Basarabia ${ }^{58}$.

3) Organizaţia de partid din Basarabia putea exista ca o organizaţie unică, care să cuprindă întreaga regiune, cu condiţia existenţei unui aparat ilegal şi a activiştilor profesionişti care să deservească acest aparat. Potrivit lor, necesitatea creării unui astfel de aparat era determinată de „teroarea poliţienească, care domnea în Basarabia, şomajul general în rândurile intelighenţiei revoluţionare şi a clasei muncitoare, precum şi de faptul că majoritatea activiştilor basarabeni erau compromişi şi se aflau sub supravegherea făţişă a Siguranţei române" ${ }^{\text {"59 }}$.

Nedorind să îşi asume responsabilitatea de a activa în Basarabia în condiţiile descrise, comitetul regional basarabean a decis să se autodizolve. Drept urmare a acestei decizii a plecat din Basarabia un număr semnificativ de bolşevici, inclusiv cei din nucleul de conducere, care, potrivit semnatarilor declaraţiei, erau „cele mai bune forţe ale mişcării comuniste, călite în activitatea revoluţionară". Ei s-au stabilit cu traiul în Rusia. ${ }^{60}$

În urma acestor constatări, semnatarii declaraţiei propuneau realizarea următoarelor sarcini organizatorice: a) restabilirea aparatului ilegal de partid, folosind în acest sens ,,cadre de ilegalişti profesioniş̧ti şi mijloace financiare, iar în

\footnotetext{
${ }^{56}$ Ibidem, f. 26.

${ }^{57}$ Ibidem.

${ }^{58}$ Ibidem, f. 26-27.

${ }^{59}$ Ibidem, f. 27.

${ }^{60}$ Ibidem.
} 
privinţa Basarabiei o legătură nemijlocită cu Rusia pentru transportarea literaturii ruse"; b) excluderea din componenţa C.C. al P.C. din România a „grupului de politicieni burghezi care au uzurpat conducerea partidului (Pauker, Cruceanu, Macovei etc.)” şi reorganizarea C.C. prin cooptarea „reprezentanţilor din provinciile nou-alipite şi a muncitorilor revoluţionari din cadrul organizaţiilor opoziţioniste (Iaşi, Galaţi etc.)"; c) întoarcerea în Basarabia a activiştilor de partid care au plecat, sarcină „realizabilă din punct de vedere tehnic doar în prezenţa condiţiilor indicate” mai sus etc. De asemenea, ei rugau Comisia pentru problema română să accepte participarea reprezentanţilor bolşevicilor basarabeni aflaţi la Moscova la discuţiile pentru elucidarea conflictului existent. ${ }^{61}$

Declaraţia respectivă a fost semnată de către 16 bolşevici basarabeni, printre care şi trei membri ai fostului comitet regional din Basarabia al P.C. din România, ales la conferinţa de partid din august 1922, anume M. Zalkind, fost secretar al comitetului, H. Bogopolskii şi L. Kislovskaia (Toporovskaia). ${ }^{62}$

După cum a constatat şi istoricul Ludmila Rotari, acest document este important din mai multe motive: în primul rând demonstrează existenţa unui conflict între agenţii comunişti din Basarabia şi C.C. al P.C. din România; în al doilea rând apare dorinţa celor din Basarabia de a deţine legături directe cu Rusia; în al treilea rând dovedeşte prezenţa masivă în Rusia sovietică a agenţilor comunişti ce au fost condamnaţi în România, fiind în aşteptarea unor noi ordine şi instrucţiuni. De asemenea, documentul în cauză demonstrează inexistenţa unei organizaţii în Basarabia începând din anul 1922. ${ }^{63}$

Situaţia va rămâne aproape neschimbată şi în anul următor. Potrivit unei scrisori adresate de către un grup de bolşevici basarabeni Congresului al V-lea al Internaţionalei Comuniste la începutul verii anului 1924, în Basarabia erau inexistente organizaţia regională de partid şi mişcarea comunistă, care a fost dispersată şi fărâmiţată în mici grupuri în urma schimbărilor de ordin organizatoric şi tactic din $1922 .{ }^{64}$ Autorii adresării invocau drept cauze principale ale numeroaselor conflicte între bolşevicii basarabeni şi C.C. al P.C. din România, precum şi cele ale plecării activiştilor de partid din Basarabia, „lipsa activităţii vii şi creative, inexistenţa unei organizaţii şi a unei mişcări în mase şi, ca temelie pentru acestea la rândul lor, orientarea politică faţă de mişcarea muncitorească română". ${ }^{65}$

\footnotetext{
${ }^{61}$ Ibidem, f. 27-28.

${ }^{62}$ Ibidem, f. 28. Ceilalţi semnatari sunt R. Kogan, R. Rosinskii (Pupko), N. Bogopoliskaia, I. Rakitov, Andreev (Ilieş), Covaci, C. Fişer, I. Rabinovici, K. Raevici, I. Roitman, S. Bantke, T. Mirskaia şi încă o persoană al cărei nume este indescifrabil.

${ }^{63}$ L. Rotari. Mişcarea subversivă din Basarabia în anii 1918-1924, p. 200-201.

${ }^{64}$ AOSPRM, F. 50, inv. 2, d. 149, f. 13-14.

${ }^{65}$ Ibidem.
} 
De asemenea, este relevant în acest sens şi raportul deja menţionat al comsomolistei E. Sovetova (Nora) din decembrie 1925, în care se constată caracterul fictiv al organizaţiei regionale de partid. Comsomolista basarabeană încerca să explice această situaţie pornind de la „sarcinile de o dificultate colosală” stabilite în 1922, cărora nu li s-a atras o atenţie cuvenită. Ea remarcă la sfârşitul raportului următoarele: „De acceptat drept adevărat faptul că în Basarabia nu există partid comunist, că în această parte (teritoriu - n.n) activează alte organizaţii (formaţiuni politice $-n . n$.), care au o abordare mai simplă şi mai apropiată de mase" ${ }^{66}$

Conflictul din 1922-1923 între bolşevicii din Basarabia, ce s-au refugiat în mare parte în Rusia Sovietică, şi C.C. al P.C.R., a fost aplanat temporar prin schimbările de ordin politic şi tactic impuse de Internaţionala Comunistă, iniţial prin Federaţia Comunistă Balcanică, la sfârşitul anului 1923, în raport cu aşa-zisa problema naţională din România. Conferinţa a VI-a a Federaţiei Comuniste Balcanice, care şi-a ţinut lucrările în decembrie 1923 la Berlin $^{67}$, a impus P.C.R. o rezoluţie specială privind problemă naţională, care aprecia fals că România a anexat „mari părţi ale altor popoare, aflate din punct de vedere politic, economic şi cultural pe un grad mai înalt de dezvoltare" şi stabilea lozinca eronată a autodeterminării până la despărţirea de România a unor provincii istorice. ${ }^{68}$ Prin aceasta au fost anunţate de fapt acţiunile guvernului sovietic privind problema basarabeană pentru anul 1924: Conferinţa sovieto-română de la Viena ${ }^{69}$, aşa-zisa răscoală de la TatarBunar (în fapt o operaţiune a serviciilor secrete sovietice) şi crearea unei republici sovietice pseudo-moldoveneşti în stânga Nistrului. În pofida acestor schimbări de ordin politic şi tactic care au avut printre obiectivele principale şi reanimarea mişcării comuniste în provinciile care s-au unit cu România în 1918, în Basarabia nu a existat o organizaţie regională de partid nici în anii 1924 şi 1925. Marea majoritate a agenţilor comunişti care au activat în Basarabia înainte de toamna lui 1922 se aflau în U.R.S.S. O parte din ei a fost încadrată în instituţiile şi structurile sovietice din R.A.S.S.M. Puţinii bolşevici care au rămas în Basarabia au avut o activitate nesemnificativă în această perioadă, fiind dispersaţi şi supravegheaţi neîncetat şi îndeaproape de către Siguranţa română.

\footnotetext{
66 Ibidem, inv. 3, d. 105, f. 13-14.

${ }^{67}$ După unele informaţii la Viena, iar după altele la Moscova.

${ }^{68}$ Socialismul, 29 februarie 1924.

69 De notat că mai mulţi istorici români au susţinut ideea că, fiind recunoscută de puterile europene, URSS a folosit Conferința de la Viena ca un mijloc de propagandă în legătură cu problema Basarabiei. A se vedea în acest sens Al. Boldur. Le Bessarabie et les relations russo-roumaines, Paris, 1927; G. I. Brătianu. La Bessarabie: droit nationaux et historique, Bucureşti, 1943; V.F. Dobrinescu. Bătălia diplomatică pentru Basarabia, Iaşi, 1991 etc.
} 


\section{Concluzii}

Cercetarea profundă a activităţii comuniste din Basarabia în anii 1922-1923, bazată pe studierea unui material vast de arhivă, ne permite să facem câteva concluzii de bază:

- Decizia din 1922 a C.E. al Internaţionalei Comuniste cu privire la trecerea organizaţiei regionale de partid din Basarabia în subordinea C.C. al P.C. din România a fost o acţiune tactică de moment a P.C. (b) din Rusia, dictată de noile realităţi intervenite în relaţiile sovieto-române la răscrucea anilor 1920-1921. Organizaţia comunistă din Basarabia a acceptat formal această decizie în august 1922, cu ocazia conferinţei regionale de partid.

- La începutul anului 1922, P.C. din România a demarat acţiunile de integrare a organizaţiei comuniste din Basarabia, utilizând în acest sens oportunitatea de participare în alegerile parlamentare din martie acelaşi an. Deşi a reuşit să pătrundă în Basarabia şi a obţinut anumite rezultate în sensul conlucrării cu organizaţia comunistă de aici, C.C. al P.C.R. a întâlnit în acelaşi timp o rezistenţă puternică, manifestări pregnante de separatism, tendinţe teroriste, precum şi alte piedici din partea bolşevicilor basarabeni. Această situaţie se explică prin faptul că ei au interpretat decizia privind trecerea lor în subordinea C.C. de la Bucureşti drept un act prin care era recunoscută în mod indirect Unirea Basarabiei cu România. Bolşevicii din Basarabia se orientau însă spre Rusia Sovietică şi erau eficienţi doar în condiţiile de activitatea ilegală subversivă, mizând pe o răscoală generală antiromânească în ţinut.

- Încadrarea organizaţiei comuniste din Basarabia în P.C. din România a avut două consecinţe de bază: 1) În rândurile mişcării comuniste basarabene s-a instaurat o stare de inactivitate aproape totală, însoţită de plecări a numeroşi bolşevici din Basarabia în Rusia Sovietică; 2) Divergenţele de viziuni privind perspectivele organizaţiei comuniste din Basarabia precum şi problemele de integrare ale acesteia în structurile P.C.R. au dus la un conflict pregnant între C.C. al P.C. din România, pe de o parte, şi organizaţia de partid basarabeană, pe de altă parte. Drept urmare a conflictului, la sfârşitul anului 1922 comitetul regional din Basarabia a P.C.R. s-a autodizolvat, iar mişcarea comunistă din ţinut a fost paralizată totalmente. Mai multe documente de arhivă, unele din ele inedite, ne relevă despre inexistenţa unei organizaţii comuniste în Basarabia în perioada noiembrie 1922-1925. 